\title{
OCCURRENCES OF THE FOSSIL DIPNOIFORMES IN BRAZIL AND ITS STRATIGRAPHIC AND CHRONOLOGICAL DISTRIBUTIONS
}

\author{
CARLOS EDUARDO VIEIRA TOLEDO \& REINALDO J. BERTINI \\ Núcleo de Evolução e Paleobiologia de Vertebrados, IGCE-UNESP, Avenida 24A-Nº 1515, 13506-900, Rio Claro, SP, Brazil. \\ cetoledo@rc.unesp.br; rbertini@rc.unesp.br
}

\begin{abstract}
RESUMO - Recentes registros em novas localidades fossílíferas, ampliaram a aparentemente limitada distribuição paleogeográfica de Dipnoiformes no Brasil. Os Dipnoiformes são registrados do Devoniano ao Mioceno/Plioceno em diferentes bacias geológicas brasileiras. O Paleozóico da bacia do Paraná, com cinco localidades, é o intervalo mais importante, incluindo a maior concentração de placas dentárias de Dipnoiformes em um "bone-bed" do Permiano da Formação Corumbataí (Estado de São Paulo). As localidades fossilíferas mais ricas ocorrem nas bacias do Paraná (São Paulo), de São Luís-Grajaú (Maranhão) e do Acre (Acre). Os fósseis destes depósitos mostram maior abundância e variação morfológica, comparados às outras localidades. É apresentado aqui um levantamento dos registros de Dipnoiformes fósseis no Brasil, fornecendo dados sobre estratigrafia, cronologia e correlação das localidades.
\end{abstract}

Palavras-chaves: Dipnoiformes, Brasil, biocronologia, biostratigrafia, paleocologia.

\begin{abstract}
Recent records in new fossiliferous localities have widened the apparently limited paleogeographic distribution of Dipnoiformes in Brazil. The Dipnoiformes are registred from Devonian to Miocene/Pliocene in different Brazilian geologic basins. The Paleozoic of the Paraná Basin, with five localities, is the most importat interval, including the largest concentration of Dipnoiformes dental plates in a Permian bone-bed of the Corumbataí Formation. The most fossiliferous localities occur in the Paraná Basin (São Paulo State), São Luís -Grajaú Basin (Maranhão State) and the Acre Basin (Acre State). Fossils from these deposits show the greatest morphological variation and are most abundant, compared to material from other localities.

It is presented here a check-list of the fossil dipnoan records in Brazil, providing stratigraphic, cronologic and correlation data of the localities.
\end{abstract}

Key Words: Dipnoiformes, Brazil, biochronology, biostratigraphy, paleocology.

\section{INTRODUCTION}

The knowledge of fossil Dipnoiformes is based on studies of complete skeletons (especially in the Paleozoic) and isolated dental plates. These fishes appeared in the Lower Devonian and during this period there was an important phylogenetic explosion, occupying both marine and continental waters on a global scale. By the Jurassic, their distribution became restricted to the Southern Hemisphere and North America. During Paleogene times, they were confined exclusively to continental areas of the late Gondwana paleocontinent, specifically South America, Africa and Australia. Schultze (1992) identified eighteen families of Dipnoiformes, of which nine are Devonian, two Carboniferous, two Permian, one Carboniferous/Permian, one Mesozoic and three Mesozoic/Cenozoic in age. Currently, only three living genera occur (all in continental environments): Neoceratodus, Protopterus and Lepidosiren, which are found in Australia, Africa, and South America, respectively.
Until recently, fossil remains of Dipnoiformes had been recorded in only a few localities in Brazil (Figure 1): from the Paleozoic of the Paraná Basin (in the states of Rio Grande do Sul, Paraná, São Paulo and Mato Grosso) and Parnaíba Basin (in the State of Maranhão); Mesozoic of the Bauru Basin (State of São Paulo), Araripe Basin (State of Ceará) and São Luís - Grajaú Basin (State of Maranhão); and Cenozoic of the Acre Basin (State of Acre). However, new discoveries have expanded considerably the number of known occurrences.

Institutional Abbreviations. MCP, Museu de Ciências e Tecnologia, Porto Alegre; MN, Museu Nacional do Rio de Janeiro; UFAC, Universidde Federal do Acre, Rio Branco; UFMA, Universidade Federal do Maranhão, São Luís; UFRJ, Universidade Federal do Rio de Janeiro, Rio de Janeiro; and URC, Universidade Estadual Paulista, Campus Rio Claro, Rio Claro. 


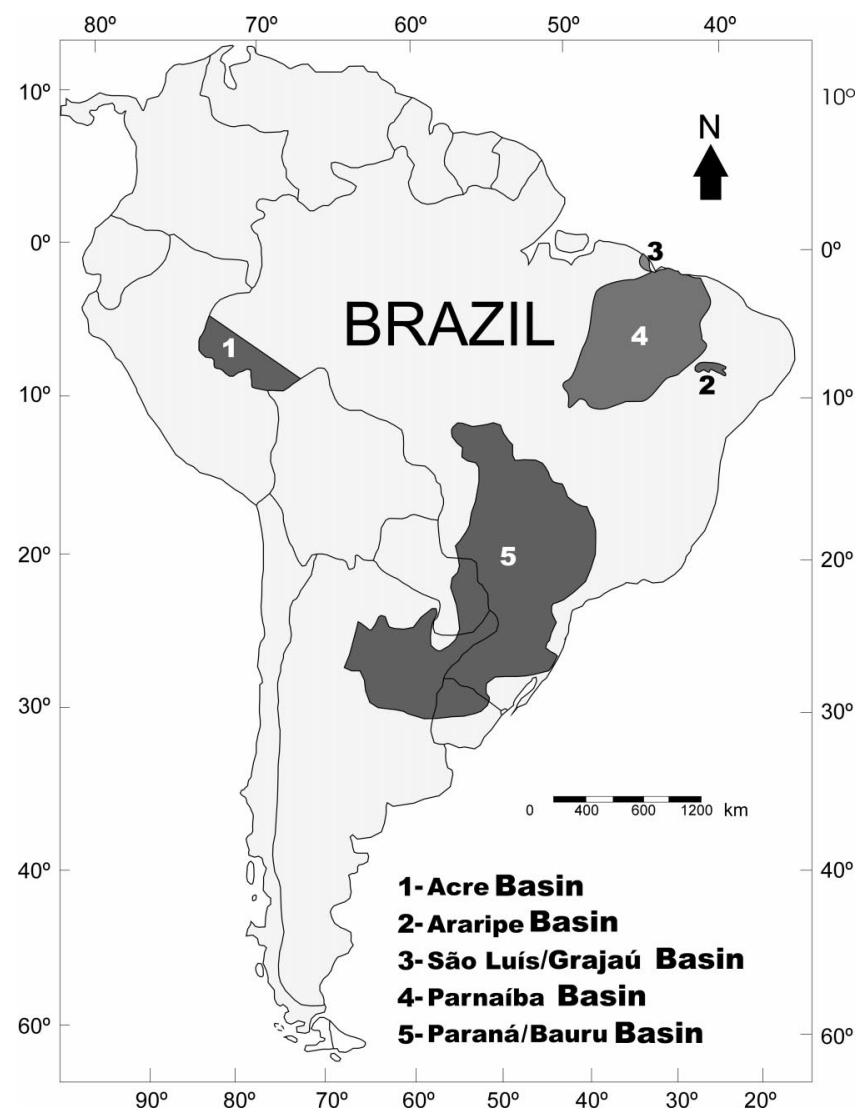

Figure 1. Location of the Brazilian sedimentary basins with Dipnoiformes occurrences (modified from Petri \& Fúlfaro, 1983).

\section{PARANÁ BASIN}

According to Milani (1997), the Paraná Basin is a wide tectonic depression (ca. 1.400,000 $\mathrm{km}^{2}$ ) situated in central-eastern South America, including areas in Brazil, Paraguay, Uruguay and Argentina. Deposits extend from Upper Ordovician to Early Cretaceous, and rest on the pre-Cambrian basement. Fossil Dipnoiformes were found in Corumbataí, Rio do Rasto and Santa Maria formations. A trace-fossil assigned to Dipnoiformes was recorded in the Ponta Grossa Formation (see below).

\section{Ponta Grossa Formation}

According to Milani (1997) the Ponta Grossa Formation occurs in the states of Paraná, Mato Grosso and Goiás. It is composed of shales and siltstones, with intercalations of very fine-grained gray sandstones (Schneider et al., 1974).

The oldest supposed record attributed to Dipnoiformes in the Paraná Basin (Fernandes \& Carvalho, 2002), is very controversial. It is a tubular burrow, slightly narrowed and curved, with elliptical transversal section and external transversal corrugations, inclined or not relative to the longitudinal axis. It is $13 \mathrm{~cm}$ in length and $5 \mathrm{~cm}$ in diameter
(Figure 2) and it was found in a succession of shales and sandstones from the marine Devonian Ponta Grossa Formation in the state of Mato Grosso, situated on state highway MT-319, about $15 \mathrm{~km}$ north of the municipality of Aquino. Fernandes \& Carvalho (2002) believed the morphology and dimensions of the ichnofossil to be compatible with the burrows characteristic of these animals, and concede that Dipnoiformes from marine and continental waters have similar habits. However, the absence of any skeletal remains of Dipnoiformes, until now, in the Ponta Grossa Formation, makes the association of that paleoichnological structure difficult. An open interpretation is assumed with respect to the organism responsible for the trace-fossil, since many scavenger organisms are also present in this unit.

\section{Corumbataí Formation}

The Corumbataí Formation is the uppermost geological unit of the Passa Dois Group in the State of São Paulo. It is considered Middle to Late Permian in age (Toledo et al.,

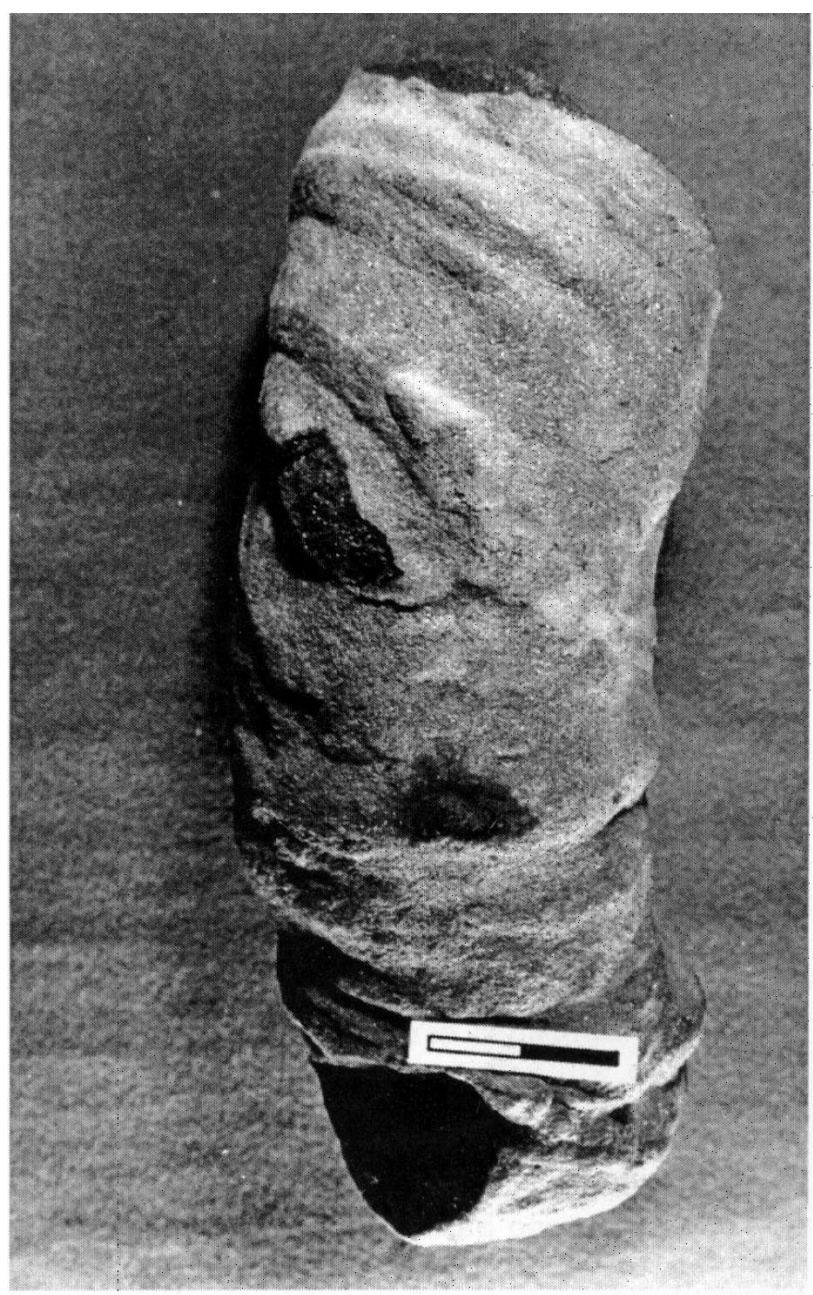

Figure 2. UFRJ-DG14-1C. A tubular burrow from the Ponta Grossa Formation, Paraná Basin attributed to Dipnoiformes (from Fernandes \& Carvalho, 2002). 
1997a). Its thickness is variable, reaching about $200 \mathrm{~m}$ (Maranhão, 1986). It is composed of massive siltstones, dark-gray to gray-purple or reddish in color, and rhythmic purple siltstones and fine-grained sandstones, sometimes with wavy structures and presenting lenticular layers, which contain bivalve shell-beds and fossil fish (Ragonha, 1984). Occasionally there are lenses of fine-grained sandstones and limestone layers, sometimes silicified (Maranhão, 1995). According to Souza et al. (1991) the depositional systems of the Corumbataí Formation are marine, offshore deposits, transitional between shore face and deeper sea, on a prograding tidal plain, with limited occurrence of bars and lagoons. Toledo et al. (1997b) suggested a marine platform depositional system, evidenced by the sedimentary structures, such as mud cracks and hummocky cross stratifications.

This formation have been correlated to Teresina Formation (State of Rio Grande do Sul; Würdig-Maciel, 1975) and to the Estrada Nova Formation in Southern Brazil (State of Paraná; Thomaz Filho et al., 1976). The occurrence of pollens related to the Lueckisporites virkkiae Zone interval from Marques-Toigo (1991) favors a Kazanian age (Maranhão, 1995). Recently, Toledo et al. (1997a) noticed the existence of Petalodontiformes in the Corumbataí Formation. This fact would define the unit as Late Permian, because that group of Chondrichthyes does not cross the Paleozoic/Mesozoic boundary (Benton, 1997).

According to Mezzalira (1989), the fossil content of the Corumbataí Formation is quite diversified. There are stromatolites, indicating a shallow marine depositional environment, with warm and oxygenated waters, low terrigenous input, and occasional high salinity; many bivalves, such as Pinzonella, Plesiocyprinella, Jacquesia and Ferrazia (Simões \& Fittipaldi, 1988); and bivalve shell-beds formed by storms and hydraulic reworking (Simões et al., 1994).

Three Dipnoiformes occurrences have been recorded in the Corumbataí Formation. The first is situated on the Wilson Finardi Highway (SP-191), in the municipality of Rio Claro (22 $22^{\prime} 55^{\prime}$ S, $46^{\circ} 42^{\prime} 43^{\prime}$ 'W). In this locality, it is exposed in an outcrop about $22 \mathrm{~m}$ high and $200 \mathrm{~m}$ in length, with fossiliferous levels (shell-beds and bone-beds). It is composed of reddish laminated siltstones, intercalated with laminae and lenses of very fine-grained, whitish sandstones up to $20 \mathrm{~cm}$ thick. Laminations and hummocky structures are observed locally, both in the silty and sandy layers. These structures, as well as the presence of very fragmented teeth and rounded dental plates, demonstrate the effects of variableintensity storm events and significant predepositional transport.

In the upper portion of this exposure, there is a bone-bed situated above a silicified bivalve shell-bed. This lenticular bone-bed is $3 \mathrm{~cm}$ thick and $30 \mathrm{~m}$ wide, with occurrences of Dipnoiformes (Figure 3) and Petalodontiformes dental plates, teeth and scales of Palaeonisciformes. These fossils are intermixed with carbonate cemented quartz grains and phosphatic materials. The abundant paleoichthyological content makes this layer the most important fossiliferous level of this outcrop. There is a second bone-bed situated in the middle portion of the outcrop, thinner than the first one (about $0.5 \mathrm{~cm}$ ), but it also contains teeth and scales of Palaeonisciformes and some isolated teeth of Xenacanthiformes.

The second locality is situated on the Raposo Tavares Highway, km 209, (23 31'54" S, 48 26'22” W). The sequence is composed of siltstones and limestones, with colors varying from gray to green and reddish, and intercalations of very fine-grained sandstone laminae, with a dominant carbonate matrix. According to Ragonha (1984), this outcrop has the most important concentration of Elasmobranchiformes remains in the Corumbataí Formation in the State of São Paulo.

The layer with a high concentration of Elasmobranchiformes remains is situated on the lower portion of the outcrop. It has a thickness of about $5 \mathrm{~cm}$, and is composed of very finegrained sandstone, with rounded grains and carbonate matrix. It also contains many fragments of Dipnoiformes dental plates, conical teeth of Palaeonisciformes; spines and teeth of Xenacanthiformes and Hybodontiformes.

The third locality is situated on the Ívens Vieira Road, near the municipality of Angatuba, km $1.2\left(23^{\circ} 31^{\prime} 10.5^{\prime \prime} \mathrm{S}\right.$,
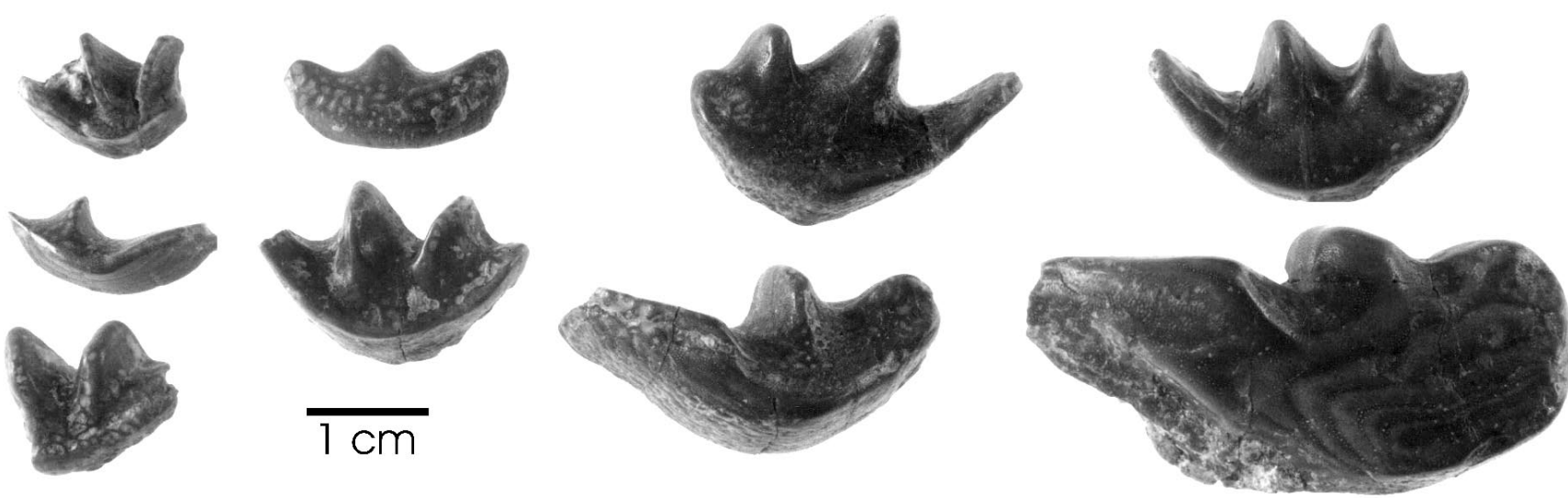

Figure 3. URC P. 261 to URC P. 269, dental plates of Dipnoiformes from the Corumbataí Formation (Paraná Basin), municipality of Rio Claro. 


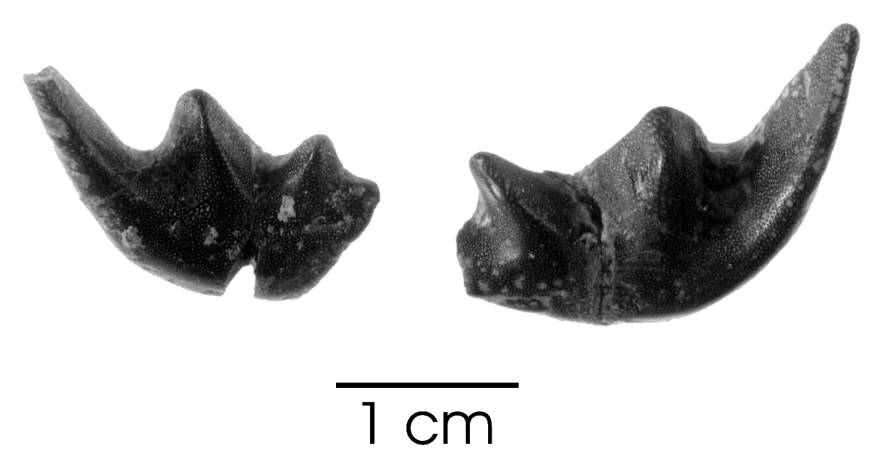

Figure 4. URC P. 270 to URC P. 271, dental plates of Dipnoiformes from the Corumbataí Formation (Paraná Basin), municipality of Angatuba.

$\left.48^{\circ} 23^{\prime} 43.2^{\prime \prime} \mathrm{W}\right)$ The sequence consists of intercalations of cream-colored sandstones and cream to reddish siltstones/ limestones. The layer with fossil fish remains is located in the lower portion of the outcrop, with a thickness of about $30 \mathrm{~cm}$. It consists of very fine-grained sandstones and carbonate matrix, with many fragments of chert, including Dipnoiformes dental plates (Figure 4), elongated conical teeth of Paleonisciformes, and many fragments of spines and isolated teeth of Xenacanthiformes.

\section{Rio do Rasto Formation}

White (1908) designated this sedimentary section as the Rio do Rasto Red-Beds, situated in the states of Santa Catarina and Paraná, and included it in the São Bento Series. The Rio do Rasto Formation is situated in the upper portion of the Passa Dois Group including two Dipnoiformes occurrences in the states of Paraná and Rio Grande do Sul. Ragonha (1989) reported the presence of Dipnoiformes dental plates in the northeastern part of the State of Paraná, in the municipality of Santo Antônio da Platina, $\mathrm{km} 42$ of the interstate highway BR-153. It is a $110 \mathrm{~m}$ thick outcrop composed of brown-reddish calciferous laminated very fine-grained sandstone, presenting sub-rounded grains, corresponding to the upper portion of that geological unit (Rohn, 1988). Associated to the Dipnoiformes dental plates, almost complete Palaeonisciformes, ganoid scales, fragments of skull bones, fin-rays, actinopterygian and Xenacanthiform teeth, cycloid scales and conchostracans were found.

Fossil fish remains were collected in a locality named Posto Queimado assigned to Morro Pelado Member of this formation, in the municipality of São Gabriel. The lithology is composed of brown conglomerates with layers of reddish siltstones, which according to Lavina (1991), were formed in a continental paleoenvironment. The assemblage includes Hybodontiformes spines, Dipnoiformes and Palaeonisciformes ganoid scales, amphibian skull and pareiasaurs (Richter \& Langer, 1998; Malabarba et al., 2002).

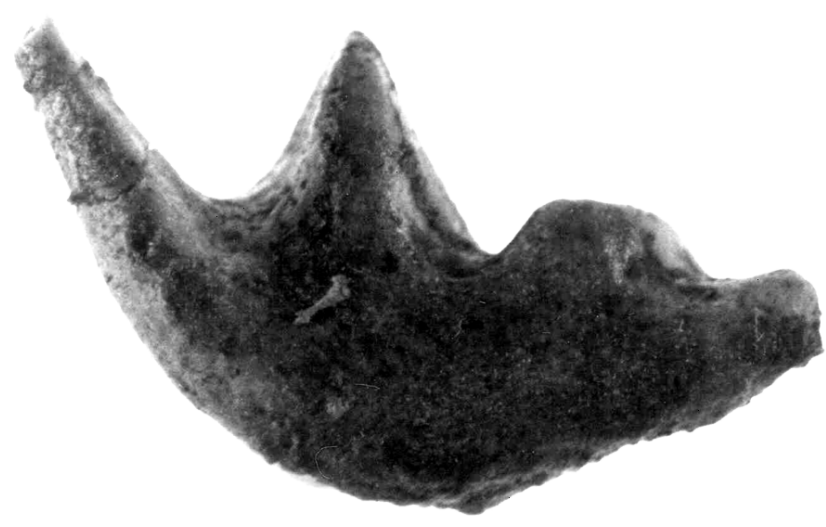

\section{$5 \mathrm{~mm}$}

Figure 5. MCP 4267-PV, Dipnoiformes dental plate of from the Posto Queimado locality, in the Rio do Rasto Formation (Paraná Basin).

The Dipnoiformes are represented by two dental plates. The first one $(1.98 \mathrm{~cm}$ length, $0.90 \mathrm{~cm}$ height $)$ has 3 cusps with petrodentine as the main component and was related to the Family Gnathorhizidae (Richter \& Langer, 1998). This locality is aged as Kazanian-Tatarian and this is possibly the first record of Gnathorhizidae in South America. The second one (1.94 cm length, $1.12 \mathrm{~cm}$ height) is associated with the same family, but presents four cusps (Figure 5). The dental plates associated to the Family Gnarthorizidae are similar to materials described from Paleozoic deposits in Russia.

\section{Santa Maria Formation}

The name Santa Maria Beds was proposed by Moraes Rego (1930) for siltstones and claystones within a dominantly sandy section occurring in southern Brazil. According to Petri \& Fulfaro (1983), it corresponds to the middle unit of the Rosário do Sul Group, which is also composed of Caturrita (upper) and Sanga do Cabral (lower) formations.

A Santa Maria Formation fossil locality in the municipality of São João do Polêsine has yielded palaeonisciform skull and scales, Hybodontiformes spines, amphibian bones, and a single Dipnoiformes dental plate, associated with possible cranial remains (Richter, 2001; Perez \& Malabarba, 2002). The Dipnoiformes dental plate is fragmented, with four cusps and it is interpreted as a left inferior plate fragment, with $11 \mathrm{~mm}$ of preserved length (Richter, 2001). This is the second report of Dipnoiformes in the State of Rio Grande do Sul and the first observation of Dipnoiformes and Amphibia association in this geological unit. 


\section{PARNAÍBA BASIN}

The intracratonic Parnaíba Basin contains a sequence of $3000 \mathrm{~m}$ of Paleozoic sediments. It is characterized by three deposition megacycles related to marine transgressions and regressions in the Silurian/Devonian/Carboniferous/Permian/ Triassic and Cretaceous periods (Mesner \& Wooldridge, 1964). According to Petri \& Fúlfaro (1983), the Upper Carboniferous/Permian sequence includes the Piauí, Pedra de Fogo, Motuca and possibly Sambaíba formations.

\section{Pedra de Fogo Formation}

The Pedra de Fogo Formation (Plummer, 1946) crops out in the Pedra de Fogo Valley River, between the municipalities of Pastos Bons and Nova York. Its thickness varies from 25 to $189 \mathrm{~m}$, which has been determined by sub-surface investigations. It is composed of gray, brown and purple shales, intercalated with dolomitic layers and siliceous concretions (Faria Jr. \& Trunckendrodt, 1980 a), sandstones and siltstones, extending above to the intercalations of shales with chert, containing intra-formational breccia. According to Faria Jr. \& Trunckendrodt (1980 b), the Pedra de Fogo Formation was deposited in an epicontinental restricted shallow marine paleoenvironment, which progressed to deltaic and estuarine. Psaronius trunks, and varied remains of pecopterideans and gymnosperms, are associated with chert horizons (Lima Filho, 1998).

The Dipnoiformes remains were identified by Silva Santos (1990) as being members of the families Sagenodontidae, Lepidosirenidae and Ceratodontidae (as the description does not include illustrations of the specimens, detailed information depends on the type-material examination). The material described by Silva Santos (1990) was collected from an outcrop situated about $6 \mathrm{~km}$ south of the municipality of Pastos Bons, on the road to Nova York. It is in a horizon composed of a thin layer of breccia with limonitic cement, which contains small fragments of bones, teeth, fin spines, scales and coprolites. Many remains are abraded and fragmented, indicating predepositional transport. Other fossil fish (Silva Santos, 1946, 1990) from this unit include different groups of Chondrichthyes (Xenacanthiformes, Ctenacanthiformes and Holocephali;), Osteichthyes (Palaeonisciformes, Coelacanthiformes), in addition to the labyrinthodont amphibian Prionosuchus plummeri. Faria Jr $\&$ Truckendrodt $(1980$ b) reported the presence of stromatolites. An Early Permian age was suggested based on the association of labyrinthodont amphibian (Prionosuchus), palynomorphs, ostracods and fishes (Mesner \& Wooldridge, 1964; Barberena, 1972). Lima \& Leite (1978), however, proposed an Early/Middle Permian age, considering the association of sporomorphs, paleoflora (Psaronius) and paleoichthyofauna.

\section{BAURU BASIN}

The Bauru Group deposits occupy the major portion of western plateau in the São Paulo State, but it is also present in the states of Minas Gerais, Goiás and Mato Grosso. According to Milani (1997), this depositional sequence reaches up to $300 \mathrm{~m}$, consisting of predominantly sandy sediments in a depositional context, with great alluvial, fluvial and eolian processes. Fernandes \& Coimbra (1994) described essentially sandy deposits, accumulated in a braided fluvial palaeoenvironment, with ephemeral lakes and marginal alluvial fans. It is divided into the Araçatuba, Adamantina, Uberaba and Marília formations.

\section{Adamantina Formation}

The Adamantina Formation was proposed by Soares et al. (1979) for facies mainly characterized by layers of very fine-grained sandstones, rose to brown in color, cross bedding stratifications, intercalated with red to gray mudstones, siltstones and mudstones, massive or with plane-parallel stratifications, wave ripples and micro-cross beddings. It is the most widespread geological unit in the western part of the State of São Paulo, and has a thickness of around 160 to 190 m (Landim et al., 1980). It is rich in fossils, containing remains of mollusks, ostracods, conchostracans, fishes, turtles, crocodylomorphs, maniraptoriformes, sauropods and mammals (Bertini et al., 1993).

In the municipality of Santo Anastácio, the presence of the Family Neoceratodontidae (Figure 6) was reported based on isolated dental plates attributed to Neoceratodus sp (Gayet \& Brito, 1989; Bertini et al., 1993).

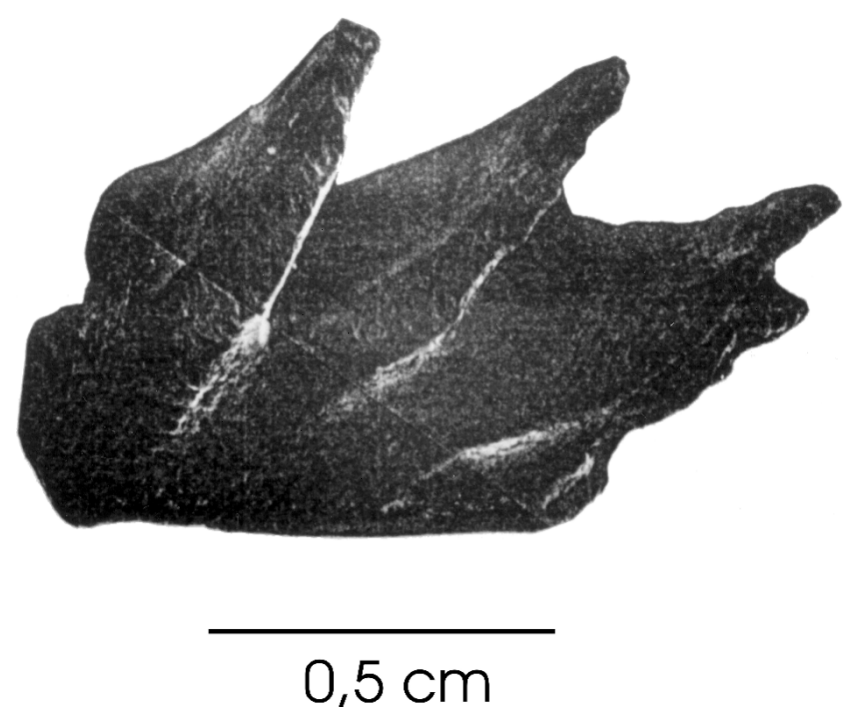

Figure 6. URC P.10, dental plate fragment of Dipnoiformes from the Adamantina Formation, Bauru Basin (from Bertini, 1993). 


\section{ARARIPE BASIN}

The Araripe basin contains Paleozoic and Mesozoic deposits, and is the biggest interior basin of northeastern Brazil, occupying about $9000 \mathrm{~km}^{2}$. It is located mainly in the State of Ceará, but also extends into Piauí and Pernambuco states. It is of great palaeontological importance, due to high concentrations of fossil fish remains in the Araripe Group sediments, especially the Santana Formation. It includes Cariri, Brejo Santo, Missão Velha, Abaiara, Barbalha, Santana and Exu formations (Assine, 1992).

\section{Brejo Santo Formation}

The Brejo Santo Formation, located in the eastern part of the Araripe Basin, was defined by Gaspary \& Anjos (1964). This geological unity is about $450 \mathrm{~m}$ thick, and is composed of reddish shales and claystones, siltstones and calcareous layers, locally green striped or spotted. There are intercalations of medium to fine-grained sandstones and thin laminae of argillaceous limestones, which are rich in ostracods and fish remains. Berthou (1990) considered it Early Cretaceous. The occurrence of non-marine biota indicates a continental sedimentation in fluvial and lacustrine systems, characterized by oxidizing conditions which are favorable to formation of red-beds. Viana \& Cavalcante (1989) also interpreted the formation as representing a lacustrine palaeoenvironment.

Neoceratodus sp was first recognized in the Araripe Basin based on isolated tooth plates from the Brejo Santo Formation (Brito et al., 1994). Silva \& Azevedo (1992) described an upper dental plate, collected in the Brejo Santo Formation, from an outcrop on the road from Missão Velha to Milagres, about $2 \mathrm{~km}$ east of the Missão Velha, State of Ceará. The fossil (Figure 7) is an elongated left dental plate, with an abraded convex masticatory surface and six ridges. There is a punctuated ornamentation on the occlusal surface

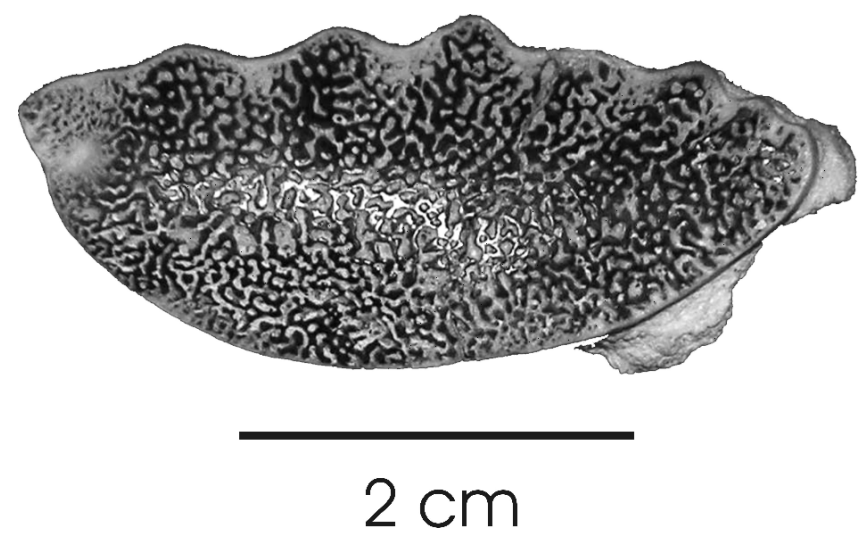

Figure 7. MN-4345-V, Dipnoiformes dental plate from the Brejo Santo Formation, Araripe Basin. due to wearing. Firstly the specimen was assigned to Neoceratodus sulamericanus (Silva \& Azevedo, 1992). However, later Silva \& Azevedo (1996) reconsidered, identifying it as Neoceratodus sp., and being morphologically allied to Neoceratodus gregory and $N$. djelleh.

\section{SÃO LUÍS-GRAJAÚ BASIN}

The São Luís - Grajaú Basin is an elongated graben of approximately $15,000 \mathrm{~km}^{2}$, located along the northern and northeastern coasts of Maranhão State. It is composed predominantly of estuarine and marine sediments, deposited during the early Cenomanian (Rossetti, 1996a). Rossetti (1996a, b; 1997) and Rossetti \& Truckenbrodt (1997) recognized three sedimentary sequences forming Itapecuru Group: Undifferentiated Unit (early/middle Albian), Alcântara Formation (late Albian-Cenomanian) and Cujupe Formation (Late Cretaceous-Tertiary).

\section{Alcântara Formation}

The Alcântara Formation consists of reddish fine to coarse-grained sandstones, with conglomeratic layers showing incipient plane parallel and cross bedding stratifications. There are intercalations of claystones and argillaceous siltstones of varied colors. Surface exposures are extensive, suggesting an average thickness of about $200 \mathrm{~m}$. Below the surface, it reaches $600 \mathrm{~m}$.

Lima \& Leite (1978) suggested a continental fluvial paleoenvironment, with lacustrine plains, in a semi-arid climate based on the oxidized character of the deposits. The most extensive outcrop of this geological unit is the Coringa Flagstone, situated on Cajual island (São Marcos bay). It was first noticed by Martins (1996), and is comprised of an aggregate of strongly fragmented, abundant and reworked fossils, whose biota is composed of permineralized plant trunks, fishes, crocodylomorphs, maniraptoriformes, sauropods, showing strong pre-depositional transport. The fish remains include Hybodontiformes fin spines, Lepidotes scales, Mawsonia bone fragments and fish rays (Medeiros \& Schultz, 2001). Besides, two Dipnoiformes species (Figure 8) are recognized in the Laje do Coringa (Cajual Island) attributed to Ceratodus africanus and Asiatoceratodus cf. tiguidiensis (Castro et al., 2004)

Cunha \& Ferreira (1980) reported Dipnoiformes dental plates found associated with angiosperm leaves and reptilian teeth, on the Itaqui port, São Luís island, in sediments currently known as Alcântara Formation. The Dipnoiformes material includes a left mandibular (holotype) and a right palatal (paratype) plates, which were assigned to a new species: Ceratodus brasiliensis

It is $38 \mathrm{~mm}$ in length and $20 \mathrm{~mm}$ in height, with five defined cusps almost straight, parallel, oriented slightly backward, with the exception of the first cusp, which is more 

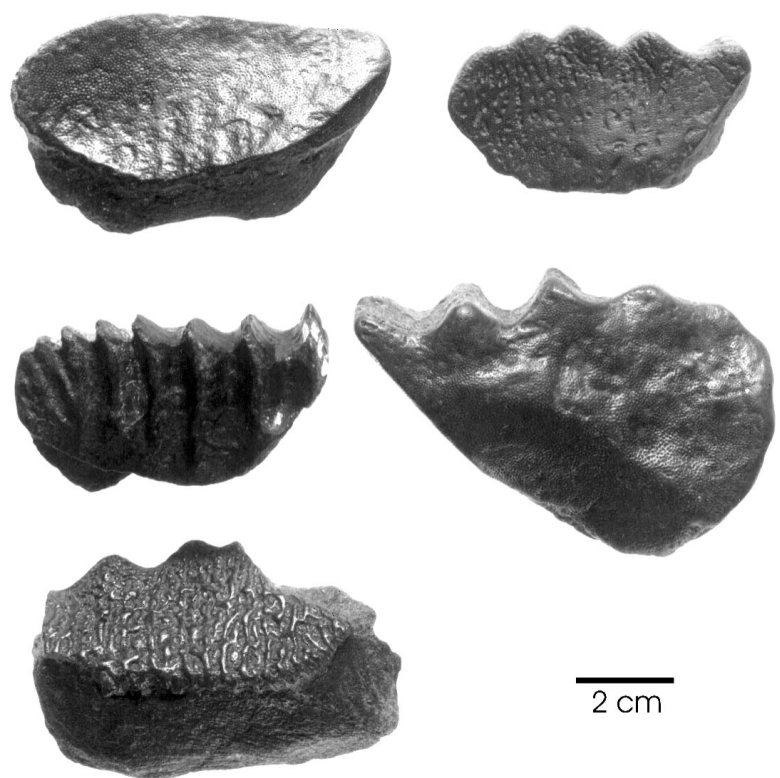

Figure 8. UFMA $1.40 .128,1.40 .73,1.40 .033,1.40 .037,1.40 .039$ Dipnoiformes dental plates from the Alcântara Formation, São Luís Basin.

robust. Martin (1984) considered Ceratodus brasiliensis synonymous of Neoceratodus africanus.

The first record of the genus Asiatoceratodus was recognized by Dutra \& Malabarba (2001) from the Itapecuru River near to the Itapecuru-Mirim municipality as Asiatoceratodus sp. An upper right tooth plate with $5.2 \mathrm{~mm}$ in length and $1.5 \mathrm{~mm}$ in height.

The Dipnoiformes present in the São Luís - Grajaú Basin are very similar to those from Africa, such as the specimens attributed to Ceratodus africanus and the genus Asiatoceratodus.

\section{ACRE BASIN}

Caputo et al. (1971) revalidated the term created by Moraes Rego (1930), elevating the Solimões series to formation, encompassing deposits from Paleocene to Pleistocene which covers the greater part of the states of Acre and Amazonas. The Solimões Formation occupies an area of about $1,000,000 \mathrm{~km}^{2}$ in Brazil, not occurring to the east of the Purus Plateau.

\section{Solimões Formation}

This geological unit is composed of sandstones, siltstones and clays of continental origin (Latrubesse et al., 1997). Its maximum exposed thickness is $70 \mathrm{~m}$, but it reaches $1800 \mathrm{~m}$ below the surface. It crops out along the Acre, Iacó, Purús, Juruá and Moa rivers, being divided into two facies: an high energy channel facies, composed of reddish-to-brown sandstones with some sparse gravel layers, with cross-bedding; and a low energy facies (floodplain, lacustrine, paludal deposits) made up of gray-to-green claystones and siltstones, with plane-parallel laminations and massive structures.

Silva Santos (1987) described Lepidosiren megalos, based on a partial cephalic skeleton and five dental plates coming from the Cenozoic deposits (upper Miocene-early Pliocene) cropping out in the Juruá and Purús valleys $\left(09^{\circ} 19^{\prime} \mathrm{S}, 70^{\circ} 20^{\prime} \mathrm{W}^{\circ}\right)$, in the State of Acre. The cephalic skeleton consists of a partially preserved neurocranium (cranial length is about $10 \mathrm{~cm}$ ), the upper dentition, the right mandibular ramus with its dentition, and a right palatal dental plate. This material contributed to knowledge of the fossil Lepidosirenidae cranial structure. It measured up to 2 $\mathrm{m}$ in length, about four times larger than a corresponding living Lepidosiren, whose maximum length is around $50 \mathrm{~cm}$. The dental plates ( $4 \mathrm{~cm}$ length) have three ridges, radiating like a fan (Figure 9). The differences between fossils and recent dental plates, except the size, are not extensive, with few angular variations. But the cranial differences are notable. In addition to this large specimen, other Dipnoiformes, attributed to Lepidosiren, were collected in the Eocene of Argentina and Oligocene of Africa, showing similar sizes to the living Lepidosiren paradoxa. Large Osteoglossoidei scales have been collected from the same outcrop (Silva Santos, 1987). The gigantism is observed in some representatives of the Tertiary fauna from Amazonia, including fishes, reptiles and mammals.
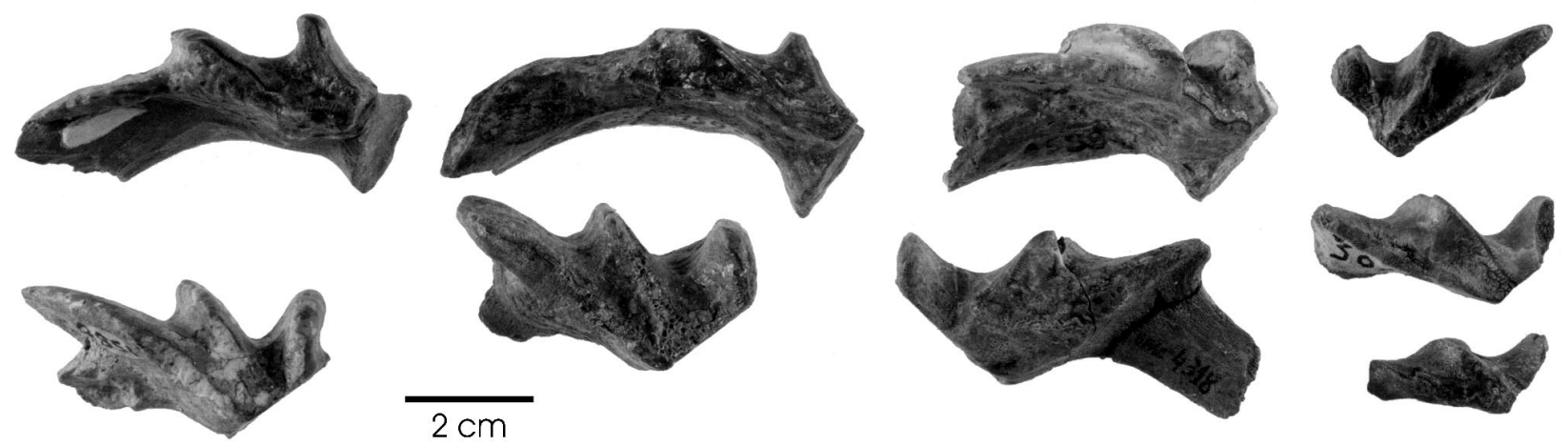

Figure 9. UFAC 2651, 3448, 2588, 1589, 4318, Dipnoiformes dental plates from the Solimões Formation, Acre Basin. 


\section{DISCUSSION AND CONCLUSIONS}

The dental plates found in the Rio do Rasto and Corumbataí formations are attributed to the Ceratodontidae and Gnarthorizidae families. These plates are similar to some forms, Ceratodus madagascariensis, C. guentheri, C. frazieri and Metaceratodus, described for Mesozoic deposits from North America, Africa and Australia. However, the Brazilian occurrences are much older (Permian) and this similarity must be considered very suspicious.

Brazilian Dipnoiformes have been identified in the Paraná, Bauru, Parnaíba, São Luis and Acre basins. The Paraná Basin contains the greatest abundance of Dipnoiformes fossil occurrences, with four localities identified. The earliest dipnoan record is a Devonian trace-fossil which consists of a narrow, curved burrow interpreted very doubtfully as having been made by a Dipnoiformes.

The most important concentration of Dipnoiformes dental plates is found in bone-beds from the Upper Permian Corumbataí Formation, Paraná Basin, in the state of São Paulo. The presence of the families Ceratodontidae and Gnarthorizidae is clear in the Paleozoic deposits from the Paraná Basin.

The Araripe Basin is known for its remarkable palaeoichthyofauna. Nonetheless, it had not shown, until now, complete Dipnoiformes specimens in any of its geological units. Only isolated dental plates, from a stratigraphic level, not very rich in fossil fishes, have been recognized.

The presence of the Family Neoceratodontidae in Brazilian deposits is questionable. There is no consensus in the literature regarding the validity of the African taxa transferred to this family, which are similar to morphotypes from the Cretaceous of Brazil. Martin (1982) had assigned many African species to the Family Neoceratodontidae, but other researchers have changed that assumption. The genus Neoceratodus has been utilized for the Australian Recent species, but Kemp \& Molnar (1981) cited the presence of Neoceratodus forsteri for the Early Cretaceous of Australia. Martin $(1982,1984)$ preferred to include some Ceratodontidae in the genus Neoceratodus, assuming its chronological distribution from Jurassic to Holocene, considering Ceratodus restricted to Jurassic.

Large Dipnoiformes remains, recovered from the Acre Basin, reinforce the phenomenon of gigantism also observed in other fishes, reptiles (especially testudines and crocodylomorphs) and mammals in this Cenozoic basin.

\section{ACKNOWLEDGEMENTS}

The authors are grateful to Fundação de Amparo a Pesquisa do Estado de São Paulo for financial support (Project 01/12575-0). For providing information, specimens, photographs and access to collections, we thank Martha Richter (The Natural History Museum), Maria C. Malabarba
(Pontifícia Universidade Católica do Rio Grande do Sul), Ismar S. Carvalho (UFRJ), Manuel Alfredo de Medeiros (Universidade Federal do Maranhão), Sérgio Alex K. de Azevedo (MN), and Edson Guilherme (UFAC). Assistance of Rubens C. Monteiro, Paulo Mello and Fernando with the photos and figures and of Allen H. Fetter and Anne Kepple with the English text is gratefully acknowledged.

\section{REFERENCES}

Assine, M.L. 1992. Análise estratigráfica da Bacia do Araripe, Nordeste do Brasil. Revista Brasileira de Geociências, 22(3): 289-300.

Barberena, M.C. 1972. South American Late Paleozoic Tetrapods. Anais da Academia Brasileira de Ciencias, 44(Suplemento): 67-75.

Benton, M. 1997. Vertebrate Palaeontology. London, Chapman \& Hall, 452 p.

Berthou, P.Y. 1990. Le Bassin d'Araripe et lês petis bassins intracontinentaux voisins (NE du Brésil): formation et evolution dans le cadre de l'ouverture de l'Atlantique Equatorial. Comparaison avec les bassins Ouest-Africains situes dans lê même contexte. In: SIMPÓSIO SOBRE BACIA ARARIPE E BACIAS INTERIORES DO NORDESTE, 1, 1990. Atas, Crato, p. 113-134.

Bertini, R.J.; Marshall, L.G.; Gayet, M. \& Brito, P. 1993. Vertebrate faunas from the Adamantina and Marília formations (Upper Bauru Group, Late Cretaceous, Brazil) in their stratigraphic and paleobiogeographic context. Neues Jarbuch fur Geologie, Palaontologie Abhandlungen, 188(1):71-101.

Brito, P.M.; Bertini, R.J.; Martill, D.M. \& Salles, L.J. 1994. Vertebrate fauna from the Missão Velha Formation (Lower Cretaceous, N.E. Brazil). In: SIMPÓSIO SOBRE AS BACIAS CRETÁCICAS BRASILEIRAS, 3, 1994. Boletim de Resumos, Rio Claro, UNESP, p. 139-140.

Castro, D.F.; Toledo, C.E.V.; Sousa, E.P. \& Medeiros, M.A. 2004. Nova ocorrência de Asiatoceratodus (Osteichthyes, Dipnoiformes) na Formação Alcântara, Eocenomaniano da Bacia de São Luís, MA, Brasil. Revista Brasileira de Paleontologia, 7(2):245-248.

Cunha, F.L. \& Ferreira, C.S. 1980. Um dipnoi na Formação Itapecuru (Cenomaniano), Maranhão, Brasil: In: CONGRESSO LATINOAMERICANO DE PALEONTOLOGIA Y BIOESTRA- TIGRAFIA, 2, 1980. Actas, Buenos Aires, 1:1-9.

Dutra, M.F.A. \& Malabarba, M.C.S.L. 2001. Peixes do Albiano-Cenomaniano do Grupo Itapecuru no Estado do Maranhão, Brasil. In: D. F. Rossetti; A. M. Góes, \& W. Truckenbrodt (eds.) O Cretáceo na Bacia de São Luís - Grajaú, MPGE, p. 191-208.

Faria Jr., L.E. \& Truckendrodt, W. 1980a. Estratigrafia e petrografia da Formação Pedra de Fogo, Permiano da Bacia do Maranhão. In: CONGRESSO BRASILEIRO GEOLOGIA, 31, 1980. Anais, SBG, Belém, 2:740-754.

Faria Jr., L.E. \& Truckendrodt, W. 1980b. Estromatólitos na Formação Pedra de Fogo, Permiano, Bacia do Maranhão. In: CONGRESSO BRASILEIRO GEOLOGIA, 31, 1980. Anais, SBG, Belém, 5:3056-3067. 
Fernandes L.A. \& Coimbra, A.M. 1994. O Grupo Caiuá (Ks): revisão estratigráfica e contexto deposicional. Revista Brasileira de Geociências, 24(3):164-176.

Fernandes, A.S. \& Carvalho, I.S. 2002. Uma provável escavação de dipnóico na Formação Ponta Grossa, Devoniano da Bacia do Paraná. Arquivos do Museu Nacional, 60(3):207-211.

Gaspary, J. \& Anjos, N.F.R. 1964. Estudo hidrogeológico de Juazeiro do Norte - Ceará. Recife, Superintendência para o Desenvolvimento do Nordeste, 25 p. (Série Hidrogeologia 3).

Gayet, M. \& Brito, P.M. 1989. Ichthyofaune nouvelle du Crétacé Supérieur du Groupe Baurú (etats de São Paulo et Minas Gerais, Brésil). Geobios, 22(6):841-847.

Kemp, A. \& Molnar, R.E. 1981. Neoceratodus forsteri from the Lower Cretaceous of New South Wales, Austrália. Journal of Paleontology, 55:211-217.

Landim, P.M.B.; Soares, P.C.; Gama-Júnior, E.G. 1980. Estratigrafia do nordeste da bacia Sedimentar do Paraná. Rio Claro, DGGA/IGCE/UNESP, 77 p.

Latrubesse, E.M.; Bocquentin, J.; Santos, J.C.R. \& Ramonelli C.G. 1997. Paleoenvironmental model for the Late Cenozoic of Southwestern Amazônia: Paleontology and Geology. Acta Amazônica, 27(2):103-118.

Lavina, E.L. 1991. Geologia sedimentar e paleogeografia do Neopermiano e Eotriássico (intervalo Kazaniano - Scytiano) da Bacia do Paraná. Programa de Pós-Graduação em Geociências, Universidade Federal do Rio Grande do Sul, Tese de Doutoramento, $335 \mathrm{p}$.

Lima Filho, F.P. 1998. A seqüência permo - pensilvaniana da Bacia do Parnaíba. Programa de Pós-Graduação em Geociências, Universidade de São Paulo, Tese de Doutoramento, 155 p.

Lima, E.A.M. \& Leite, J.F. 1978. Projeto estudo global dos recursos minerais da Bacia Sedimentar do Parnaíba. Integração Geológica Metalogenética. Recife, Departamento Nacional de Produção mineral/CPRM, 16 v.

Maisey, J.G. 1996. Discovering fossil fishes. New York, Henry Holt \& Company, 223 p.

Malabarba, M.C.S.L.; Abdala, F.; Weiss, F.E. \& Perez, P.A. 2002. New data on the late Permian vertebrate fauna of Posto Queimado, Rio do Rasto Formation, southern Brazil. Revista Brasileira de Paleontologia, 6:49-54.

Maranhão, M.S.A.S. 1986. Contribuição ao conhecimento da malacofauna das camadas basais da Formação Corumbatai (Permiano), Estado de São Paulo. Programa de Pós-Graduação em Geociências, Universidade de São Paulo, Dissertação de Mestrado, 88 p.

Maranhão, M.S.A.S. 1995. Fósseis das formações Corumbataí e Estrada Nova do Estado de São Paulo: subsídios ao conhecimento paleontológico e bioestratigráfico. Programa de Pós-Graduação em Geociências, Universidade de São Paulo, Tese de Doutoramento, $362 \mathrm{p}$.

Marques-Toigo, M. 1991. Palynobiostratigraphy of the Southern Brazilian Neopaleozoic Gondwana sequence. In: INTERNATIONAL GONDWANA SYMPOSIUM, 7, 1991. Proceedings, São Paulo, p. 503-515.

Martin, M. 1982. Nouvelles donées sur la phylogénie et la systématique dês Dipneustes postpaléozoiques, conséquences stratigraphiques et paléogéographiques. Geobios, Mémoire Spéciale, 6:53-64.

Martin, M. 1984. Révision des arganodontidés et des néoceratodontidés (Dipnoi, Ceratodontiformes) du Crétacé africain.
Neues Jahrbuch fur Geologie und Palaontologie Abhandlungen, 169(2):225-260.

Martins, F.J.C. 1996. Levantamento de aspectos geológicos da parte setentrional da Ilha de São Luís e áreas adjacentes. Programa de Pós-Graduação em Geologia, Universidade Federal do Rio de Janeiro, Dissertação de Mestrado, 98 p.

Medeiros, M.A. \& Schultz, C.L. 2001. Uma paleocomunidade de vertebrados do Cretáceo médio, Bacia de São Luís. In: D. F. Rossetti; A. M. Góes, \& W. Truckenbrodt (eds.) O Cretáceo na Bacia de São Luís - Grajaú, MPGE Editoração, p. 209-221.

Mesner, J.C. \& Wolldridge, L.C. 1964. Estratigrafia das bacias paleozóicas e cretácea do Maranhão. Tradução Condensada de C. W. M. Campos. In: Boletim Técnico PETROBRÁS, Rio de Janeiro, 7(2):137-164.

Mezzalira, S. 1989. Os fósseis do Estado de São Paulo. São Paulo, Instituto Geológico, 141 p.

Milani, E.J. 1997. Evolução tectono-estratigráfica da Bacia do Paraná e seu relacionamento com a geodinâmica fanerozóica do Gondwana sul-ocidental. Programa de Pós-Graduação em Geociências, Universidade Federal do Rio Grande do Sul, Tese de Doutoramento, $255 \mathrm{p}$.

Moraes Rego, L.F. 1930. A geologia do petróleo no Estado de São Paulo. Rio de Janeiro, Serviço Geológico Mineralógico Brasil, 110 p. (Boletim 46).

Perez, P.A. \& Malabarba, M.C. 2002. A Triassic freshwater fish fauna from the Paraná Basin, in Southern Brazil. Revista Brasileira de Paleontologia, 3:27-33.

Petri, S. \& Fúlfaro, V.J. 1983. Geologia do Brasil. São Paulo, EDUSP, $631 \mathrm{p}$.

Plummer, F.B. 1946. Bacia do Parnaíba. Rio de Janeiro, Relatório Conselho Nacional Petróleo, p. 87-134.

Ragonha, E.W. 1984. Taxionomia de dentes e espinhos isolados de Xenacanthodii (Chondrichthyes, Elasmobranchii) da Formação Corumbataí. Considerações cronológicas e paleoambientais. Programa de Pós-Graduação em Geociências, Universidade de São Paulo, Tese de Doutoramento, 166 p.

Ragonha, E.W. 1989. Placas dentárias de Dipnoi no Grupo Passa Dois (P - Tr) da Bacia do Paraná. Apreciações ambientais, climáticas, cronológicas e estratigráficas: In: CONGRESSO BRASILEIRO DE PALEONTOLOGIA, 11, 1989. Anais, Curitiba, 1:195-206.

Richter, M. 2001. First lungfish (Sarcopterygii: Dipnoi) from the Santa Maria Formation, Triassic of Rio Grande do Sul State, Brazil: In: CONGRESSO BRASILEIRO DE PALEONTOLOGIA, 17, 2001. Boletim de Resumos, Rio Branco, p. 121.

Richter, M. \& Langer, M.C. 1998. Fish remains from the Upper Permian Rio do Rasto Formation (Paraná Basin) of Southern Brazil: Journal of African Earth Sciences, 27:158-159.

Rohn, R. 1988. Bioestratigrafia e paleoambientes da Formação Rio do Rasto da borda leste da Bacia do Paraná (Permiano Superior, Estado do Paraná). Programa de Pós-Graduação em Geociências, Universidade de São Paulo, Dissertação de Mestrado, $331 \mathrm{p}$.

Rossetti, D.F. 1996a. Sequence stratigraphic significance of two estuarine valley fills: the upper Itapecuru Formation in the São Luís Basin, Northern Brazil. Acta Geologica Leopoldensia, 43: 111-125.

Rossetti, D.F. 1996 b. Facies analysis and sequence stratigraphic significance of the Upper Itapecuru Formation, São Luís Basin, 
Northern Brazil. Boulder. University of Colorado at Boulder, Tese de Doutoramento, $219 \mathrm{p}$.

Rossetti, D.F. 1997. Facies analysis of the lower succession of the Upper Itapecuru Formation, São Luís Basin, northern Brazil. In: M. L. Costa \& R. Angelica (eds.) Contribuições à geologia da Amazônia, Falângola, p. 241-284.

Rossetti, D.F. \& Truckenbrodt, W. 1997. Revisão estratigráfica para os depósitos do Albiano - Terciário Inferior (?) na Bacia de São Luís, Maranhão. Boletim do Museu Paraense Emílio Goeldi, Série Ciências da Terra, 9:29-41.

Schneider, R.L.; Mühlmann, H.; Tommasi, E.; Medeiros, R.A.; Daemon, R.F.; Nogueira, A.A. 1974. Revisão estratigráfica da Bacia do Paraná. In: CONGRESSO BRASILEIRO DE GEOLOGIA, 28, 1974. Anais, SBG, 1:41-65.

Schultze, H.-P. 1992. Fossilium catalogous 1: Animalia (Dipnoi). Amsterdan, Kugler Publications, 464 p.

Silva Santos, R. 1946. Duas novas formas de elasmobrânquios do Paleozóico do Meio Norte, Brasil. Anais da Academia Brasileira de Ciências, 28(4):281-285.

Silva Santos, R. 1987. Lepidosiren megalos n. sp. do Terciário do Estado do Acre, Brasil. Anais da Academia Brasileira de Ciências, 59:375-384.

Silva Santos, R. 1990. Paleoictiofáunula da Formação Pedra de Fogo, Bacia do Parnaíba, Nordeste do Brasil: HolocephaliPetalodontidae. Anais da Academia Brasileira de Ciências, 62(4):347-355.

Silva, V.G. \& Azevedo, S.A. 1992. Um dipnóico da Formação Brejo Santo, Jurássico da Chapada do Araripe, Ceará, Brasil. Anais da Academia Brasileira de Ciências, 64:419-420.

Silva, V.G. \& Azevedo, S.A. 1996. Um dipnóico da Formação Brejo Santo, Eocretáceo da Chapada do Araripe, Ceará, Brasil. Acta Geológica Leopoldensia, 43(19):43-58.

Simões, M.G. \& Fittipaldi, F.C. 1988. As conchas fósseis da região de Rio Claro. Arquivos do Município de Rio Claro, 75 p.

Simões, M.G.; Torello, F.F. \& Rocha-Campos, A.C. 1994. Proximal storm shell - beds or coquinas in the Corumbataí Formation (Pinzonella illusa assemblage; Late Permian) in Rio Claro, SP,
Paraná Basin, Brazil. In: CONGRESSO BRASILEIRO DE GEOLOGIA, 38, 1994. Resumos, SBG, 3:226-227.

Soares, P.C.; Landim, P.M.B.; Fúlfaro, V.J.; Amaral, G.; Suguio, K.; Coimbra, A.M.; Sobreiro Neto, A. F.; Giancursi, F.; Correa, W. A. G. \& Castro, C. G. J. 1979. Geologia da região sudoeste do Estado de São Paulo. In: SIMPÓSIO REGIONAL DE GEOLOGIA, 2, 1979. Atas, Rio Claro, 2: 307-319

Souza, S.H.M.; Suguio, K. \& Castro, J.C. 1991. Sedimentary facies of the Estrada Nova and Corumbataí formations (Late Paleozoic of the Paraná Basin) in the State of São Paulo, Brazil. In: INTERNATIONAL GONDWANA SYMPOSIUM, 7, 1991. Proceedings, São Paulo, p. 161-172.

Thomaz Filho, A.; Cordani, U.G. \& Kawashita, K. 1976. Aplicação do método $\mathrm{Rb}$ - Sr na datação de rochas sedimentares argilosas da Bacia do Paraná. In: CONGRESSO BRASILEIRO DE GEOLOGIA, 29, 1976. Anais, SBG, Belo Horizonte, p. 289-302.

Toledo, C.E.V.; Brito, P.M.M. \& Bertini, R.J. 1997 a. Chronological meaning about the presence of petalodonts (Holocephali incertae sedis) in the Corumbataí Formation of São Paulo State (Brazil). In: CONGRESSO BRASILEIRO PALEONTOLOGIA, 15, 1997. Boletim de Resumos, São Pedro, p. 80.

Toledo, C.E.V.; Masson, M.R. \& Bertini, R.J. 1997 b. Litho-sedimentological analysis of a bone - bed with vertebrate remains from Corumbataí Formation (Upper Permian) near Rio Claro City, State of São Paulo (Brazil). In: CONGRESSO BRASILEIRO PALEONTOLOGIA, 15, 1997. Boletim Resumos $15^{\circ}$ Congresso Brasileiro de Paleontologia, São Pedro, p. 159.

Viana, M.S.S. \& Cavalcante, V.M.M. 1989. Faciologia das formações Missão Velha e Brejo Santo, na região de Missão Velha, Bacia do Araripe, Ceará. In: SIMPÓSIO DE GEOLOGIA DO NORDESTE, 13, 1989. Atas, p. 166-169.

Würdig-Maciel, N.L. 1975. Ictiodontes e ictiodorulitos (Pisces) da Formação Estrada Nova e sua aplicação na estratigrafia do Grupo Passa Dois. Pesquisas, 5:165 p.

White, I.C. 1908. Relatório final. Rio de Janeiro, Comissão de Estudos das Minas de Carvão de Pedra do Brasil, 617 p. 